Research Article

\title{
Effect of Sintering and Concentration of Dymethylformamide on Surface Properties of Hydroxyapatite Coating on Titanium Substrate Fabricated by Electrophoretic Deposition
}

\author{
Mochammad Dachyar Effendi 1,a,", Razie Hanafi ${ }^{1, b}$, Utari Pusparini ${ }^{2, c}$, \\ and Sara Aisyah Syafira ${ }^{3, d}$ \\ ${ }^{1}$ Pusat Teknologi Material, Badan Pengkajian dan Penerapan Teknologi \\ 224th building, Puspiptek Area, Serpong, South Tangerang 15314, Indonesia \\ ${ }^{2}$ Jurusan Kimia, Fakultas Matematika dan Ilmu Pengetahuan Alam, Universitas Soedirman \\ Jl. Dr. Soeparno Karangwangkal, Purwokerto 53123, Indonesia \\ ${ }^{3}$ Department of Chemistry, Instrumental Analytical Chemistry Division, University of Southhampton \\ University Road, Southhampton, SO17 1BJ, United Kingdom
}

e-mail: dachyar.effendy@bppt.go.id*, razie.hanafi@bppt.go.id, pusparini@gmail.com, sas1n17@southampton.ac.uk

* Corresponding Author

\begin{abstract}
Hydroxyapatite (HAp) coating on metallic implant was developed to increase bioactivity of orthopaedic implant. In this work, hydroxyapatite was successfully deposited on commercially pure titanium (CP-Ti) substrate by electrophoretic deposition (EPD). This work aims to determine the effect of dimethylformamide (DMF) as dispersant for EPD suspension followed by heat treatment, on the surface morphology of the HAp coating. HAp powder was suspended in an ethanol-DMF solution with the amount of DMF designed at 0, 5, 10, and 15\% per $100 \mathrm{~mL}$ suspension. EPD was then performed successfully on all samples. After EPD, the specimens were sintered at $800{ }^{\circ} \mathrm{C}$ for 120 minutes in argon atmosphere. Surface morphology, composition, and phase of HAp coating before and after sintering were characterized by Scanning Electron Microscope, Fourier Transform Infrared Spectrometer, and X-ray Diffractometer. X-ray and IR spectra confirmed that sintering had a little effect on the chemical structure and the phase of the deposited HAp. The morphology of the surface is denser across all samples and shows distinguishable features as the amount of DMF in the system was increased. The 15\% DMF sample exhibits the mostly grooved surface after sintering. Further analysis showed that sintering reduced the EPD-related shrinkage on the surface and enhanced the size of the pores. Microstructural indication referring to previous research suggested that this type of microscopic surface is very sought after in promoting a good biological interaction between the implant and the host. Further testing must be done to confirm the effect of DMF-modified structure in living tissue.
\end{abstract}

Keywords: metal implant coating; electrophoretic deposition; hydroxyapatite; dimethylformamide

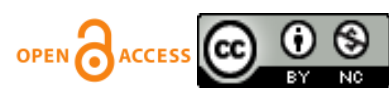


Jurnal Penelitian Fisika dan Aplikasinya (JPFA), 2020; 10(2): 90-102

\title{
Pengaruh Sintering dan Konsentrasi Dimetilformamida pada Sifat Permukaan Lapisan Hidroksiapatit pada Substrat Titanium yang Dibuat dengan Metode Deposisi Elektroforesis
}

\begin{abstract}
Abstrak
Pelapisan hidroksiapatit pada implan logam dilakukan untuk meningkatkan bioaktifitas dari implan ortopedik. Pada penelitian ini telah dilakukan pelapisan hidroksiapatit pada substrat titanium murni komersial (CP-Ti) dengan metode deposisi elektroforesis (EPD). Penelitian ini bertujuan untuk mengetahui pengaruh dimetilformamida sebagai dispersant pada suspensi EPD dan perlakuan panas terhadap morfologi permukaan lapisan. Suspensi dibuat dengan mencampurkan hidroksiapatit dalam etanol dan dimetilformamida pada berbagai konsentrasi DMF, yaitu : 0, 5, 10, dan $15 \%$. Setelah proses deposisi elektroforesis, sampel kemudian disinter pada suhu $800{ }^{\circ} \mathrm{C}$ selama 120 menit dalam suasana argon. Morfologi permukan, komposisi serta fasa yang terjadi baik sebelum dan sesudah perlakuan panas dikarakterisasi menggunakan Scanning Electron Microscope, Fourier Transform Infrared, dan X-ray Diffraction. Hasil pengamatan dalam penelitian ini menunjukkan bahwa tidak terjadi perubahan fasa yang signifikan terhadap lapisan hidroksiapatit baik sebelum maupun sesudah perlakuan panas. Namun terjadi perubahan pada penyusutan lapisan dan ukuran keporian. Adapun penambahan DMF berpengaruh pada semakin padatnya deposit seiring dengan bertambahnya volume DMF. Hasil deposisi pada sampel DMF 15\% menunjukkan sifat mikrostruktur terbaik dengan permukaan beralur yang unik setelah perlakuan panas dimana alur ini memberikan keuntungan pada peningkatan sifat biologis dari lapisan hidroksiapaitit sebagai pelapis implan logam. Pengujian lanjutan perlu dilakukan untuk mengkonfirmasi pengaruh modifikasi struktur yang terjadi pada jaringan hidup
\end{abstract}

Kata Kunci: pelapisan implan logam; deposisi elektroforesis; hidroksiapatit; dimetilformamida

PACS: 81.15.-z; 81.15.Pq; 87.85.jj

(C) 2020 Jurnal Penelitian Fisika dan Aplikasinya (JPFA). This work is licensed under CC BY-NC 4.0

Article History: Received: October 29, $2019 \quad$ Approved with minor revision: March 17, 2020

Accepted: September 25, $2020 \quad$ Published: December 31, 2020

How to cite: Effendi MD, et al. Effect of Sintering and Concentration of Dymethylformamide on Surface Properties of Hydroxyapatite Coating on Titanium Substrate Fabricated by Electrophoretic Deposition. Jurnal Penelitian Fisika dan Aplikasinya (JPFA). 2020; 10(2): 90-102. DOI: https://doi.org/10.26740/jpfa.v10n2.p90-102.

\section{INTRODUCTION}

Hydroxyapatite (HAp) coating is very popular in many modern orthopedic implants, particularly on implants used in degenerative surgery, such as hip replacement implant, bone conduction implant, and dental implant, due of its similarity with bone mineral, and its ability to promote osseointegration [1,2]. There have been many researches in the area of HAp coating on metallic implant. Some of these research incorporate techniques like solgel deposition [3], biomimetic deposition [4-6], plasma spraying [7], magnetron sputtering [8,9], electrolytic deposition
[10,11], and electrophoretic deposition $[12,13]$. In recent years, electrophoretic deposition method (EPD) has gained interest because it offers shorter deposition time, better control of the desirable thickness and morphology, and the versatility to be applied on many shapes of substrate [14].

There are some metals famous for being biocompatible and almost all of them have been manufactured to become implant products [15]. Yet, surface modification is still desired to improve many aspects of said implants because of the advantages it offers. This research will be focusing in the idea to 
exercise low cost treatment of ceramic deposition on metal surface. Such approach have been done before. For example, the deposition of HAp powder on stainless steel $316 \mathrm{~L}$ substrate with the variation of sintering temperature and deposition time has been reported in the previous research [16]. Other research were reporting on the variation of electric fields sources to deposit HAp on Titanium [12], on the variation of Hap concentration [17] and recently, on the coating of hydroxyapatite-chitosan composite on TiAl [18] and Ti6Al4V surfaces [19].

The principle of EPD is the migration of charged particles influenced by electric field in suspension. The charged particles that are suspended in a solvent medium will begin to move once current starts flowing onto the opposite electrode. The particles are supposedly, positively charged as they will be moving from the anode (positive electrode), attracted toward the substrate that acts as the cathode (negative electrode). The characteristics of the deposited layer are influenced by two groups of parameters; those related the process of EPD (voltage, deposition time, etc.) and those related to the properties of the suspension [20]. The product of EPD has a glaring, but understandable weakness, which is the weak bonding between the ceramic particles and the metallic substrates. Post-deposition process such as heat treatment is needed to enhance the bonding. However, this procedure is often resulted in cracked surface due to the particle shrinkage during the sintering process [21]. Modification on solvent properties can be designed to make a more stable suspension with better powder dispersion that makes for adherence coating to avoid cracking upon sintering. Sintering after EPD is also needed to gain a denser coating [22].

Solvent medium is an important parameter since deposition occurred in colloidal suspension. Modification by adding dispersant such as triethanolamine (TEA) had successfully produced crack-free and dense coating [23]. Other dispersants such as trisaminomethane [24], polyvinyl alcohol, and dimethylformamide [25], had also been used to improve strength, adherence, and density of coating.

In this paper, the effect of solvent composition containing ethanol and dimethylformamide as dispersant for EPD treatment will be investigated. Following the EPD treatment, the samples will be sintered under argon atmosphere to observe the full effect of the solvent modification.

\section{METHOD \\ Materials and Sample Preparation}

Commercially pure titanium (CP-Ti) plates grade 2 were used as substrates. The plates were grinded with sandpapers up to \#1000 grit and then ultrasonically cleaned in technical grade ethanol and distilled water. The plates were then immersed in a solution of nitric acid and hydrofluoric acid $(3: 1)$. Finally, they were rinsed under distilled water and dried in room temperature.

HAp powder were synthesized in the same way as in the previous research [26]. HAp powder were then diluted in the ethanolDMF solution with a DMF volume variation of $0 \%, 5 \%, 10 \%$, and $15 \%$ in ethanol. Each variation batch contains $100 \mathrm{~mL}$ of solution with $\mathrm{pH}$ of 4-4.5. The desired $\mathrm{pH}$ was adjusted with the aid of $\mathrm{HNO}_{3} \quad 1 \mathrm{M}$. Every EPD suspension was stirred for 15 minutes by magnetic stirrer, followed by ultrasonication for 30 minutes to obtain a better homogenization.

In the EPD setup, CP-Ti plate was used as the working electrode whereas the platinum electrode was used as the counter electrode. Both electrodes were submerged inside the EPD suspension, approximately $1 \mathrm{~cm}$ from the bottom of the flask. The distance between the two electrodes was $2 \mathrm{~cm}$, measured from 
the surface of the exposed area of $1 \mathrm{~cm}^{2}$. EPD was performed at $15 \mathrm{v}$ for 15 minutes. After the process, HAp-deposited sample was securely exposed to room condition for one day. Argon-assisted sintering of the sample was performed at $800{ }^{\circ} \mathrm{C}$ with a heating rate of $10^{\circ} \mathrm{C} /$ minutes for 2 hours.

\section{Sample Characterization}

X-ray diffraction (XRD) was run in Shimadzu X-ray diffractometer 7000 with 40 $\mathrm{kV} \mathrm{CuK} \alpha$ radiation using a $0.02^{\circ}$ step size. The analysis was performed to determine the change of crystal phases between the regular and the sintered samples. The Surface morphology of the deposited HAp was captured using scanning electron microscope (SEM) FEI Quanta 650. While the chemistry of the samples were examined by ATR-FTIR Thermo Scientific Nicolet iS50 at the resolution of $1 \mathrm{~cm}^{-1}$.

\section{III.RESULTS AND DISCUSSION XRD Analysis}

HAp (ICDD - PDF2 card: 00-009-0432) is expectedly appears as the dominant peaks in the diffraction patterns obtained (Figure 1a and $1 \mathrm{~b}$ ). Titanium peaks, designated as $\mathrm{Ti}$, have also rarely appear in the patterns; as observed on the 38.2, 40.2 and $53.02 \theta$ degrees. This is the proof that deposition of HAp has definitely occurred on the surface of titanium substrate. All of the $\mathrm{Ti}$ peaks represent the crystallites that occupy the (002) plane, (101) plane, and (102) plane respectively. These results are typical with pure titanium crystal, showing there is no change occurs to the titanium base metal after the EPD treatment.
HAp is still maintaining most, if not all, of their major phases after the deposited samples were subjected to sintering. The intensity of Ti peaks are decreasing with more DMF in the system, in both set of samples. This result might be attributed to a more stable medium that facilitates particles movement which results in better dispersion of the HAp powder. The Absence of $\mathrm{TiH}_{2}$, a by-product from the reaction of titanium and distilled water, is the result of a very little surface area that becomes partially hydrogenated during the EPD process. This is due to the lower working voltage the EPD in this research was run. A study performed at $15 \mathrm{v}$ with 15 minutes deposition times in alternating current (AC) shows a similar tendency on its deposited layer [27].

The intensity of HAp increases gradually between all the patterns after sintering was applied (Figure 1.b). This shows that the sintering provided the needed energy for the deposited HAp to undergo further crystallization and densification [28], and that DMF is able to retain the modification feature in the sintered samples.

In the case of sintering for titanium, XRD can be a very direct tool to determine the affected phase caused by the applied heat [29-32]. There is no oxidation product observed from figure 1.b, which validates the sintering method described before. It is possible that the optimized densification provided by the addition of DMF that change the structure of the HAp on the surface is giving more protection to the titanium substrate from reacting with oxygen. However, observation to a deeper part of the surface needs to be done to confirm this hypothesis. 


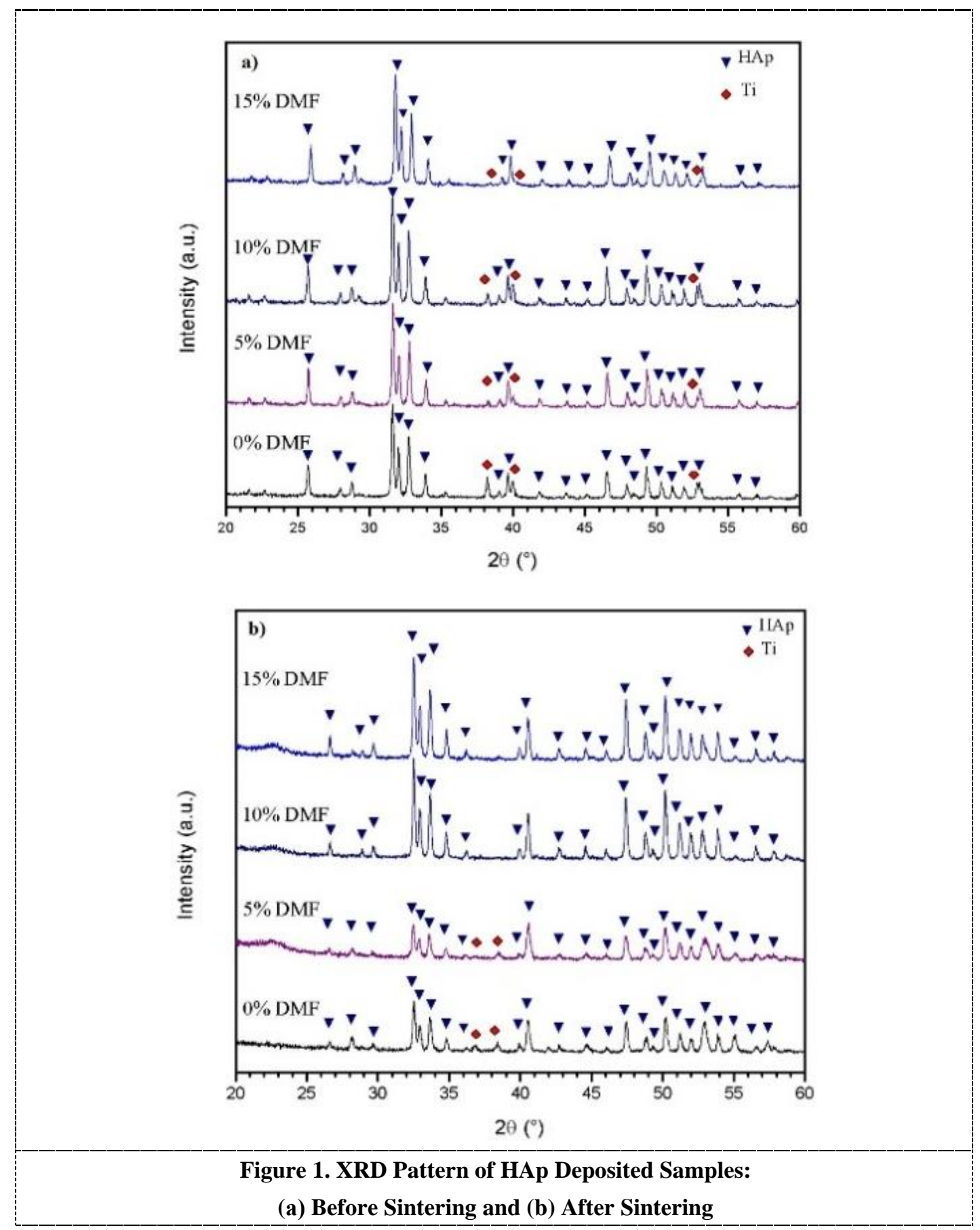

\section{FTIR Analysis}

Figure 2 shows the FTIR spectra of HAp deposited samples before and after sintering. Carbonates are known to have four vibrational modes present; $n 1, n 2, n 3$ and $n 4$. The two of which are observed in the Raman spectrum and most of the others are observable in the infrared spectrum [33]. The broad bands in the region of 1650 to $1300 \mathrm{~cm}^{-1}$ are assigned to $\mathrm{n} 3$ vibrational mode and the weak nudges at around $873 \mathrm{~cm}^{-1}$ are assigned to $\mathrm{n} 2$ vibrational mode. The $n 3$ vibrational $\left(v_{3}\right)$ carbonates appear clearer in the sintered samples spectra. Suggesting the possibility of carbonate ions release from the modified HAp that is happening in a highly elevated temperature. The n2 vibrational $\left(v_{2}\right)$ carbonates are believed to match the surface carbonate ions that belong to the reaction during the synthesis of HAp used in this study, which is confirmed in the previous work [34]. 

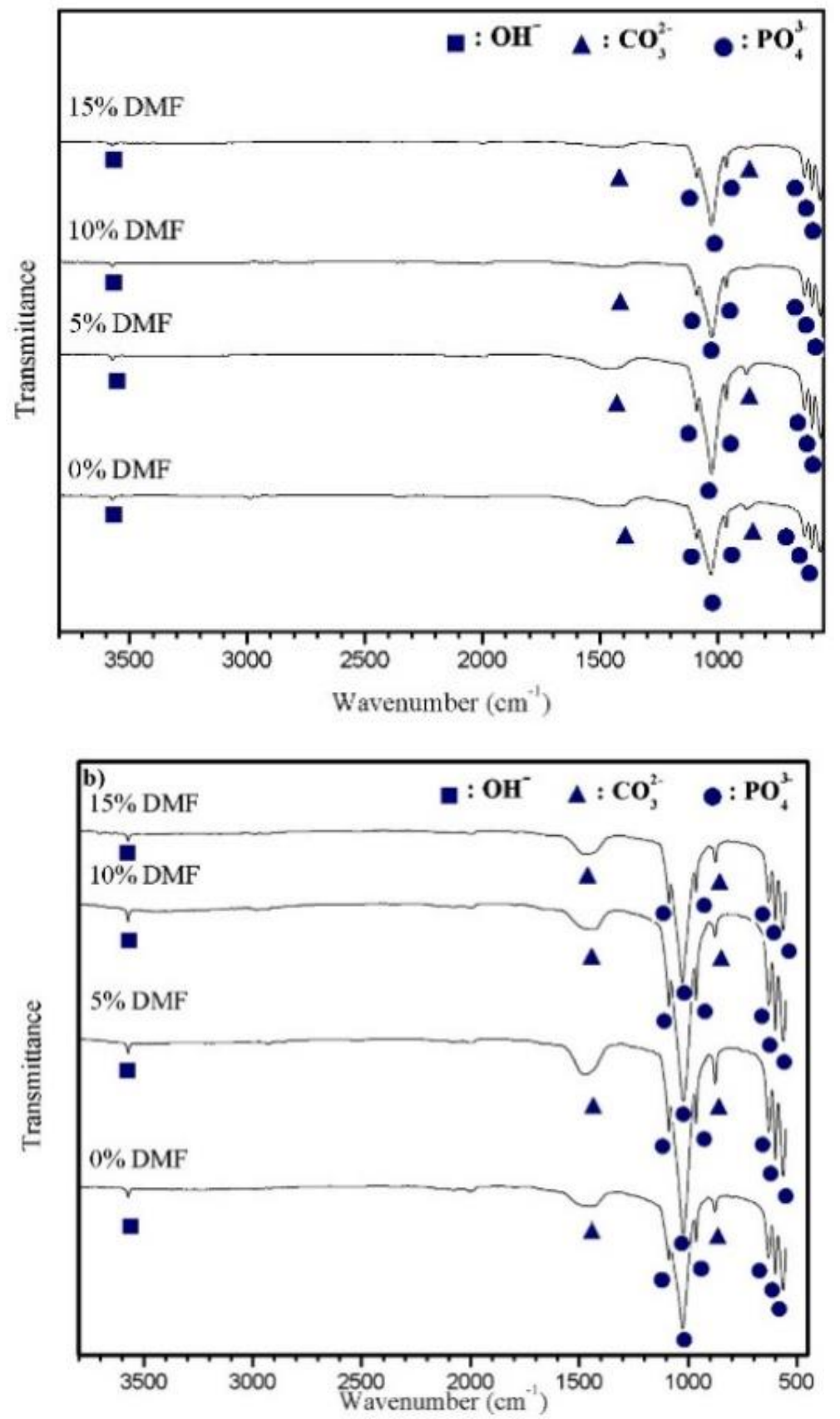

Figure 2. ATR FTIR Spectra of HAp Deposited on Titanium Subtrates by Electrophoretic Deposition:

(a) Before Sintering and (b) After Sintering at $800{ }^{\circ} \mathrm{C}$

Deposited-HAp is represented by the phosphate bands in two areas. Peaks at 1087 , 1026, and $962 \mathrm{~cm}^{-1}$ are assigned to the $\mathrm{n} 3$ phosphate bands, while the sharper peaks at 629, 598, $561 \mathrm{~cm}^{-1}$ are assigned to $\mathrm{n} 4$ phosphate bands, being in the region between 660 and $520 \mathrm{~cm}^{-1}$ [32].

The hydroxyl band appears very weakly at $3558 \mathrm{~cm}^{-1}$ due to the lack of free water involved in the process. There is only a slight difference between the spectra of non-sintered and sintered samples. These noticeable nudges in the sintered spectra come from the product of ethanol evaporation that stays within the surface composition even long after sintering.

The layout of the spectra shows that any change in chemical structure caused by DMF addition is hardly distinguishable. The comparison in Figure 3 is made to isolate both 
of the DMF-free spectra to determine the actual improvement shown from sintering on molecular level. It is apparent that almost all the peaks are stronger in the sintered sample. The intensity of the phosphate bands are enhancing significantly, proving the tremendous presence of HAp in the system.
This is also shown in the carbonate bands at around $873 \mathrm{~cm}^{-1}$. The increase of the $v_{3}$ carbonates and $v_{2}$ carbonates bands is the sign of densification of the HAp structure as a result of sintering to a temperature close to $1000^{\circ} \mathrm{C}[30]$.

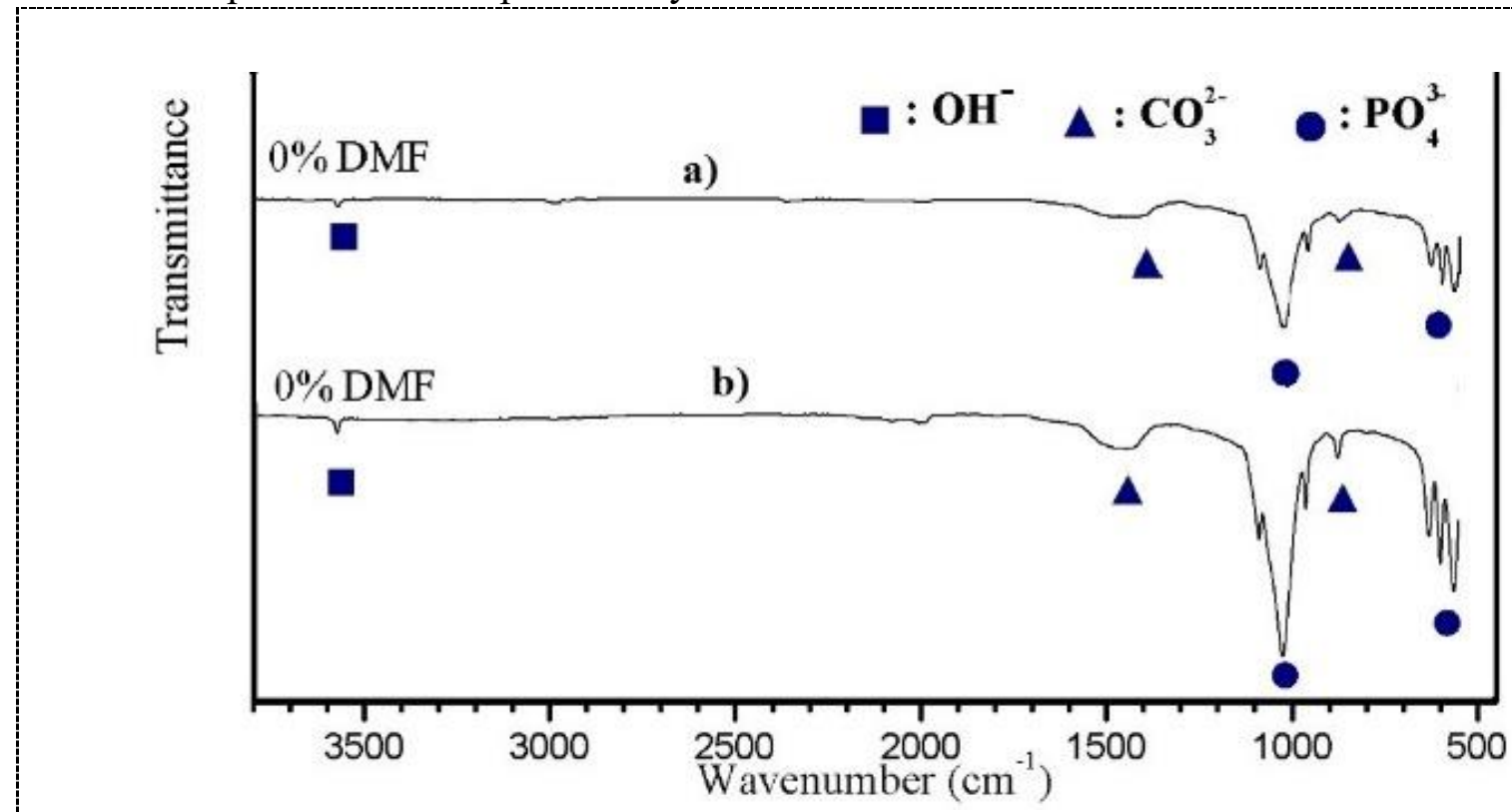

Figure 3. ATR FTIR Spectra of $0 \%$ DMF Samples: (a) Before Sintering and (b) After Sintering at $800^{\circ} \mathrm{C}$

\section{SEM Analysis}

DMF has been known to promote a better result for EPD with HAp as the main precursor [35]. The application of sintering is supposed to give a significant effect on the pore structure and morphology of the deposited samples [29,31]. The measurement of pore diameters for all samples are listed in Table 1. All the sintered samples show a decrease of maximum pore diameter. This is accompanied by the change in the pore size distribution as shown by the tightening of the size gaps for all samples. The microporosity (pore size $<10 \mu \mathrm{m}$ ) shown in all samples will promote better impregnation of biological fluids. The microchannels provided by these micropores play an active role in the cellular attraction processes on the surface [36].

The shape of the particles changes from irregular and angular in the form of agglomerates to flake-like shape with a denser body due to the sintering effect. The flake-like shape increases regularly as DMF concentration increases (Figure 4). These flake-like shape of HAp are piling on top of each other that creates intra-pore between piles. Table 1 is also showing this increasing range of pore size, which is related to the increase of DMF concentration in the solution that adds to the sintering effect that have been mentioned above.

The surface morphology has a direct correlation to the implant interaction with cells as well as wettability, texture, and chemical composition [37]. A roughen surface is formed from the EPD process (Figure 5). The sintering adds extra layers with different heights and microchannels embedded into it as large as 1-2 $\mu \mathrm{m}$ in diameter. The sintered sample is forming a very different microtopography than what have been observed before (Figure 5c). 
Jurnal Penelitian Fisika dan Aplikasinya (JPFA), 2020; 10(2): 90-102

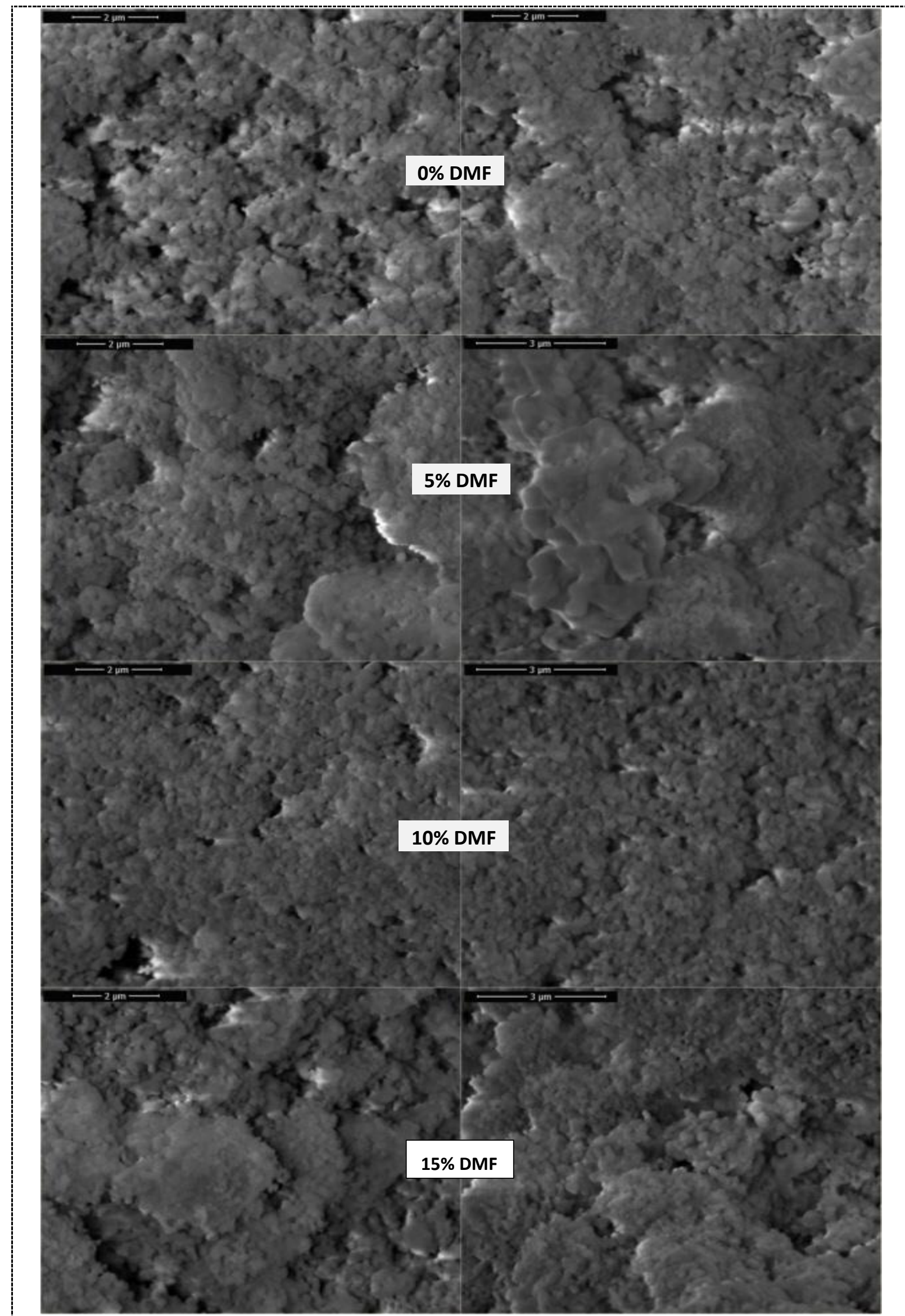

Figure 4. SEM Photographs of HAp Surfaces on Titaniun Substrates After Electrophoretic Deposition (Left Side) and After Heated at $800{ }^{\circ} \mathrm{C}$ (right side) 


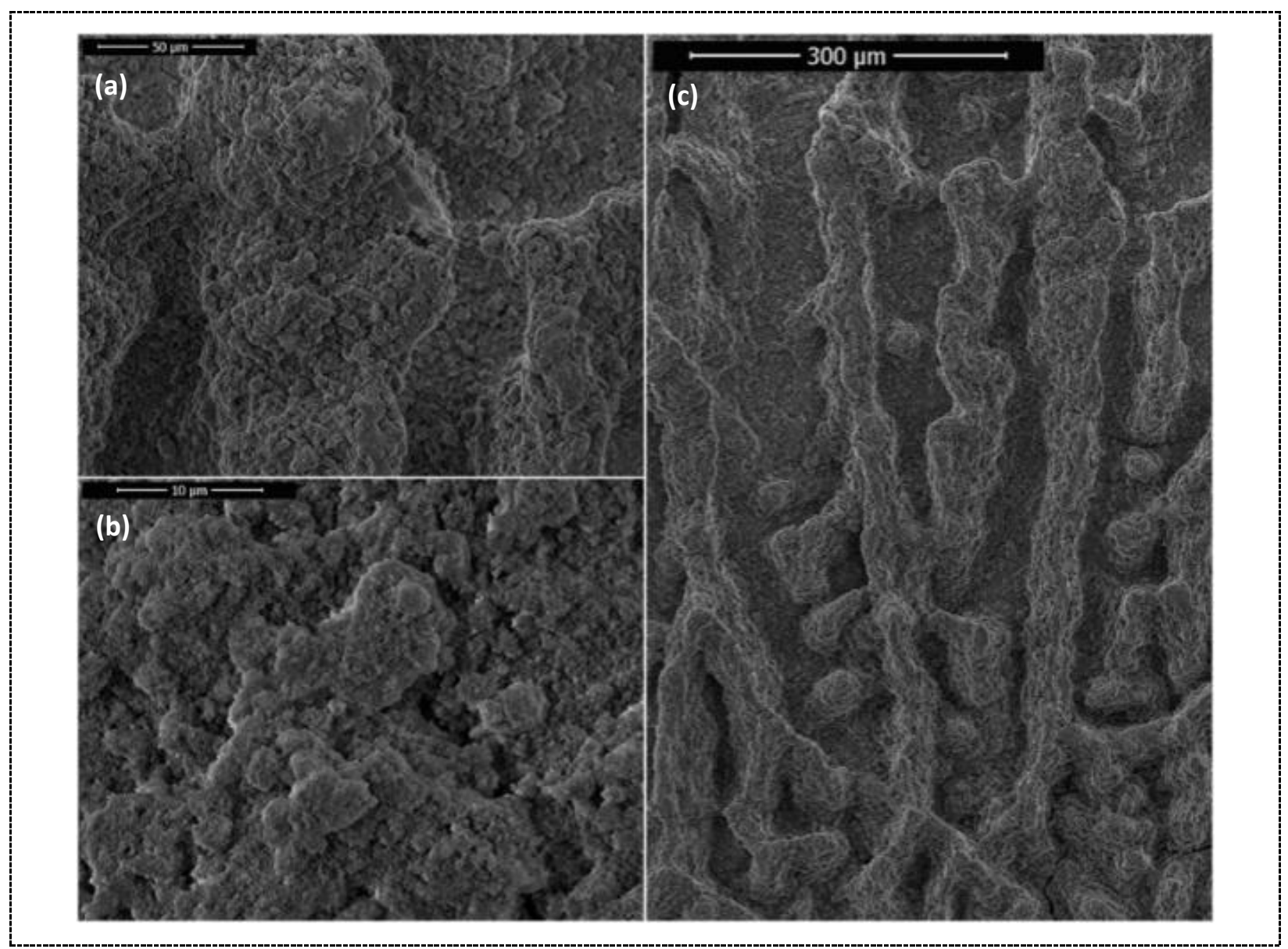

Figure 5. SEM Photographs of 15\% Sample HAp Coating After Sintering at (a) 500 mag; (b) 2500 mag; (c) 5000 mag

Table 1. Range of Pore Diameter Before and After Heat Treatment

\begin{tabular}{lll}
\hline Sample & Non-sintering & Post-sintering \\
\hline $0 \%$ & $130.7 \mathrm{~nm}-446.8 \mathrm{~nm}$ & $142.3 \mathrm{~nm}-389.0 \mathrm{~nm}$ \\
$5 \%$ & $152.5 \mathrm{~nm}-1,116 \mathrm{~nm}$ & $181.9 \mathrm{~nm}-827.5 \mathrm{~nm}$ \\
$10 \%$ & $132.3 \mathrm{~nm}-678.0 \mathrm{~nm}$ & $223.2 \mathrm{~nm}-309.6 \mathrm{~nm}$ \\
$15 \%$ & $110.9 \mathrm{~nm}-1,743 \mathrm{~nm}$ & $181.9 \mathrm{~nm}-1,500 \mathrm{~nm}$ \\
\hline
\end{tabular}

The sample with the best morphological features (15\% DMF sample) have a wider size range of pores compared to samples of other DMF concentrations (Table 1). This type of surface morphology is known to be very adaptable towards tissue and cell attachments, as it creates a favorable environment for cells and cell-extracellular matrix interaction [38]. The availability of larger pore sizes is also deemed more suitable for human osteoblasts to transverse through in order to facilitate bone growth [39].
The microstructure shows that samples with $15 \%$ DMF is the most suitable for promoting bone regeneration. However, the problem still lies in the insufficient pore size needed as a biological requirement. Various clinical studies have attested to this problem. It has been reported that the rate of bone tissue expansion of a defect rabbit bone model was higher in the implant group with large pores than in the small pores ones, where the largepores group constructs of $0.8 \mu \mathrm{m}$ to $50-400$ $\mu \mathrm{m}$ pore sizes compared to $163.6 \pm 77.1 \mu \mathrm{m}$ 
of the small ones [40]. Another research has demonstrated a higher fixation ability of porous titanium implants with $600 \mu \mathrm{m}$ average pore size. In the span of two weeks, the implant exhibited a better cortical bone growth in the rabbit's tibia than the one using a $300 \mu \mathrm{m}$ average pore size implant [41]. Based on these works, there is a need of a further research in the coating process of HAp into titanium implant to obtain a larger pore size suitable for osteoinduction.

The physical nature of the material, such as the mobility of the particles inside suspension is believed to have a certain impact on the final deposited layer. This is governed by the presence of adjunct particles with different velocity and how these charged particles affect the ion distribution and the electrical double layer around each colloidal particle. As the use of dispersant that affects the surface energy between particles is proven to have some influence to the electrophoretic nature of the reaction. Hopefully, continuous improvement can be sustained as the mechanism of hydroxyapatite for electrophoretic deposition is better understood.

\section{CONCLUSION}

The important factors of the implant surface that adhere to the biological requirements are pore size, pores interconnection, and surface roughness. Higher degree of crystallinity is also required to make a stable deposition for application of HAp on the surface of metal implant. This study shows that by adding DMF into EPD solution, a tailor-made HAp microstructure can be deposited on the surface of titanium alloy. Sintering is then needed to obtain a better densification and crystallisation of the deposited-HAp.

By modifying the DMF concentration inside the EPD solution, a various flake-like layer of HAp has been successfully obtained.
The microstructure of all of the DMF modified samples inherit this feature without any apparent micro crack on the surface. There is very little change to the crystal and chemical structures observed in the modified samples, but the sample with $15 \%$ DMF is considered the best out of the three, even prior to sintering. This is due to the range of pore sizes and morphologies this particular sample exhibits. Sintering on $15 \%$ DMF gives the deposited-HAp the widest pore range at about 1-2 $\mu \mathrm{m}$, that is needed for cellularextracellular matrix interaction. It is believed that the sintering creates additional layers and microchannels that enhances its microtomography.

\section{ACKNOWLEDGMENT}

This work is fully supported by the funding of "The Technology Development for Industrialization" entitled "The Development of Local Limestone-based Hydroxyapatite as Bone Filler for Orthopaedic and Dental Material Application", (Number: 28/GI /PPK/E/E4/2019) by The Ministry of Research and Higher Education of Indonesia.

\section{REFERENCES}

[1] Hessam H, Izman S, and Hamtaiepour S. Evaluating The Surface Properties of Hydroxyapatite Coating on Titanium Alloy Substrate. Jurnal Mekanikal. 2013; 36: 86-93. Available from:

https://jurnalmekanikal.utm.my/index.php/ju rnalmekanikal/article/view/65.

[2] Oshida Y. Hydroxyapatite: Synthesis and Applications. New York: Momentum Press; 2014.

[3] Suwanprateeb J, Suvannapruk W, Chokevivat W, Kiertkrittikhoon S, Jaruwangsanti N and Tienboon P. Bioactivity of A Sol-GelDerived Hydroxyapatite Coating on Titanium Implants In Vitro and In Vivo. Asian Biomedicine. 2018; 12(1): 35-44. DOI: https://doi.org/10.1515/abm-2018-0029. 
Jurnal Penelitian Fisika dan Aplikasinya (JPFA), 2020; 10(2): 90-102

[4] Nazir M, Ting OP, Yee TS, Pushparajan S, Swaminathan D and Kutty MG. Biomimetic Coating of Modified Titanium Surfaces with Hydroxyapatite Using Simulated Body Fluid. Advances in Materials Science and Engineering. 2015; 2015: 407379. DOI: https://doi.org/10.1155/2015/407379.

[5] Pylypchuk IV, Petranovskaya AL, Gorbyk PP, Korduban AM, Markovsky PE, and Ivasishin OM. Biomimetic Hydroxyapatite Growth on Functionalized Surfaces of Ti-6Al-4V and TiZr-Nb Alloys. Nanoscale Research Letter. 2015; 10: 338. DOI:

https://doi.org/10.1186/s11671-015-1017-x.

[6] Elkoca O, Yoruc ABH, Karakas A, and Koyun A. Hydroxyapatite Coating on Cp-Ti Implants by Biomimetic Method. Advanced Materials Research. 2012; 445: 679-684. DOI:

https://doi.org/10.4028/www.scientific.net/A MR.445.679.

[7] Cizek J J and Matejicek. Medicine Meets Thermal Spray Technology: A Review of Patents. Journal of Thermal Spray Technology. 2018; 27: 1251-1279. DOI: https://doi.org/10.1007/s11666-018-0798-8.

[8] Surmenev RA, Surmeneva MA, Grubova IY, Chernozem RV, Krause B, Baumbach T, Loza $\mathrm{K}$, and Epple M. RF Magnetron Sputtering of A Hydroxyapatite Target: A comparison Study on Polytetrafluorethylene and Titanium Substrates. Applied Surface Science. 2017; 414: 335-344. DOI:

https://doi.org/10.1016/j.apsusc.2017.04.090.

[9] Qi J, Yang Y, Zhou M, Chen Z, and Chen K. Effect of Transition Layer on The Performance of Hydroxyapatite/Titanium Nitride Coating Developed on Ti-6Al-4V Alloy by Magnetron Sputtering. Ceramics International. 2019; 45(4): 4863-4869. DOI: https://doi.org/10.1016/j.ceramint.2018.11.1 83.

[10] Lin DY, Jiang Y, and Wang XX. Electrolytic Deposition of Hydroxyapatite Coating on CoNiCrMo Substrates. Advanced
Engineering Materials. 2010; 12(1-2): B70B73. DOI:

https://doi.org/10.1002/adem.200980013.

[11] Ulasevich SA, Kulak AI, Poznyak SK, Karpushenkov SA, Lisenkov AD, and Skorb EV. Deposition of HydroxyapatiteIncorporated $\mathrm{TiO} 2$ Coating on Titanium Using Plasma Electrolytic Oxidation Coupled with Electrophoretic Deposition. RSC Advances. 2016; 6(67): 62540-62544. DOI: https://doi.org/10.1039/C6RA10560B.

[12] Kollath VO, Chen Q, Closset R, Luyten J, Traina K, Mullens S, Boccaccini AR, and Cloots R. AC vs. DC Electrophoretic Deposition of Hydroxyapatite on Titanium. Journal of the European Ceramic Society. 2013; 33(13-14): 2715-2721. DOI: https://doi.org/10.1016/j.jeurceramsoc.2013. 04.030.

[13] Farrokhi-Rad M, Khosrowshahi YB, Hassannejad H, Nouri A, and Hosseini M. Preparation and Characterization of Hydroxyapatite/Titania Nanocomposite Coatings on Titanium by Electrophoretic deposition. Materials Research Express. 2018; 5(11): 115004. DOI: https://doi.org/10.1088/2053-1591/aadbe8.

[14] Gamburg YD, Zangari G. Introduction to Electrodeposition: Basic Terms and Fundamental Concepts. In Gamburg YD, Zangari G. Theory and Practice of Metal Electrodeposition. New York: Springer; 2011: 1-25.

[15] Kumar S, Pande S, and Verma P. Factor Effecting Electro-Deposition Process. International Journal of Current Engineering and Technology. 2015; 5(2): 700-703. Available from: http://inpressco.com/factoreffecting-electro-deposition-process/.

[16] Nuswantoro NF, Budiman I, Septiawarman A, Tjong DH., and Manjas M. Effect of Applied Voltage and Coating Time on Nano Hydroxyapatite Coating on Titanium Alloy Ti6Al4V Using Electrophoretic Deposition for Orthopaedic Implant Application. IOP 
Jurnal Penelitian Fisika dan Aplikasinya (JPFA), 2020; 10(2): 90-102

Conference Series: Materials Science and Engineering. 2019; 547: 012004. DOI: https://doi.org/10.1088/1757899X/547/1/012004.

[17] Yu HN, Hsu HC, Wu SC, Hsu CW, Hsu SK, and Ho WF. Characterization of Nano-Scale Hydroxyapatite Coating Synthesized from Eggshells Through Hydrothermal Reaction on Commercially Pure Titanium. Coatings. 2020; 10(2): 112-122. DOI:

https://doi.org/10.3390/coatings10020112.

[18] Pusparini U, Effendi MD, and Hanafi R. Hydroxyapatite Coating on Titanium by Elecrophoretic Deposition from Ethanoldimethylformamide Suspensions. Proceedings of 14th International Joint Conference on Chemistry. Surakarta; 2019.

[19] Chavez-Valdez A, Shaffer MSP, and Boccaccini AR. Applications of Graphene Electrophoretic Deposition. A review. The Journal of Physical Chemistry. 2012; 117(6): 1502-1515.

DOI: https://doi.org/10.1021/jp3064917.

[20] Chen PY, Wang SF, Chien RR., Tu CS, Feng KC, Chen CS, Hung KY, and Schmidt VH. Evolution of the Microstructural and Mechanical Properties of Hydroxyapatite Bioceramics with Varying Sintering Temperature. Ceramics International. 2019; 45(13): 16226-16233. DOI:

https://doi.org/10.1016/j.ceramint.2019.05.1 $\underline{44}$.

[21] Mehta MS and Singh RP. Effects of Aging Time and Sintering Temperatures on Thermal, Structural and Morphological Properties of Coralline Hydroxyapatite. Journal of Nuclear Physics, Material Science, Radiation and Application. 2016; 3(2): 223-237. DOI: https://doi.org/10.15415/jnp.2016.32021.

[22] Teh YC, Tan CY, Ramesh S, Purbolaksono J, Tan YM, Chandra H, Teng WD, and Yap BK. Effect of Calcination on The Sintering Behaviour of Hydroxyapatite. CeramicsSilikáty. 2014; 58(4): 320-325. Available from: https://www.ceramics-

silikaty.cz/index.php?page $=\mathrm{cs}$ detail doi\&i $\mathrm{d}=131$.

[23] Jeffrey CKL, Chuan YL, Ramesh S, and Sivanesan S. The Sinterability Of Hydroxyapatite Bioceramics. Journal of Engineering Science and Technology, Special Issue on SOMCHE 2014 \& RSCE 2014 Conference. 2015; 6: 83-90. Available from: http://jestec.taylors.edu.my/Special\%20Issue \%206 SOMCHE 2014/SOMCHE\%202014 6 62015_083 090.pdf.

[24] Malina D, Biernat K, and Sobczak-kupiec A. Studies on Sintering Process of Synthetic Hydroxyapatite. Acta Biochimica Polonica. 2013; 60(4): 851-855. DOI:

https://doi.org/10.18388/abp.2013_2071.

[25] Mondal S, Hoang G, Manivasagan P, Moorthy MS, Kim HH, Phan TTV, and Oh J. Comparative Characterization of Biogenic and Chemical Synthesized Hydroxyapatite Biomaterials for Potential Biomedical Application. Materials Chemistry and Physics. 2019; 228: 344-356. DOI:

https://doi.org/10.1016/j.matchemphys.2019. $\underline{02.021 .}$.

[26] Effendi MD, Gustiono D, Ayu D, and Kurniawati F. Comparison on Mechanical Properties of Single Layered and Bilayered Chitosan-Gelatin Coated Porous Hydroxyapatite Scaffold Prepared Through Freeze Drying Method. IOP Conference Series: Materials Science and Engineering. 2017; 172: 012031. DOI:

https://doi.org/10.1088/1757-

$\underline{899 X / 172 / 1 / 012031}$.

[27] Yang Y, Wang K, Gu X, and Leong KW. Biophysical Regulation of Cell BehaviorCross Talk between Substrate Stiffness and Nanotopography. Engineering (Beijing). 2017; 3(1): 36-54. DOI: https://doi.org/10.1016/j.eng.2017.01.014.

[28] Hettich G, Schierjott RA, Epple M, Gbureck $\mathrm{U}$, Heinemann S, Mozaffari-Jovein $\mathrm{H}$, and Grupp TM. Calcium Phosphate Bone Graft 
Jurnal Penelitian Fisika dan Aplikasinya (JPFA), 2020; 10(2): 90-102

Substitutes With High Mechanical Load Capacity and High Degree of Interconnecting Porosity. Materials. 2019; 12(21): 3471-3485. DOI: https://doi.org/10.3390/ma12213471.

[29] Harun WSW, Asri RiM, Alias J, Zulkifli FH, Kadirgama K, Ghani SABC, and Shariffuddin JHM. A Comprehensive Review of Hydroxyapatite-Based Coatings Adhesion on Metallic Biomaterials. Ceramics International. 2018; 44(2): 1250-1268. DOI: https://doi.org/10.1016/j.ceramint.2017.10.1 62.
[30] Prasad S, Gaddam A, Jana A, Kant S, Sinha PK, Tripathy S, Annapurna K, Ferreira JM, Allu AR, and Biswas K. Structure and Stability of High $\mathrm{CaO}$-and P2O5-Containing Silicate and Borosilicate Bioactive Glasses. The Journal of Physical Chemistry B. 2019; 123(35): 7558-7569. DOI:

https://doi.org/10.1021/acs.jpcb.9b02455.

[31] Prakasam M, Locs J, Salma-Ancane K, Loca D, Largeteau A, and Berzina-Cimdina L. Biodegradable Materials and Metallic Implants-A Review. Journal of Functional Biomaterials. 2017; 8(4): $44 . \quad$ DOI: https://doi.org/10.3390/jfb8040044. 